\title{
Relevance of the Senior High School Curriculum in Ghana in Relation to Contextual Reality of the World of Work
}

\author{
Okrah, Abraham Kwadwo ${ }^{1, *}$, Ampadu, Ernest ${ }^{1} \&$ Yeboah, Rita ${ }^{1}$ \\ ${ }^{1}$ Department of Teacher Education, School of Educational Leadership and Administration, University of Ghana, \\ Legon, Ghana \\ *Correspondence: Department of Teacher Education, School of Educational Leadership and Administration, \\ University of Ghana, P. O. Box LG 1181, Legon, W/A, Ghana. E-mail: aokrah@ug.edu.gh
}

Received: October 28, 2019 Accepted: November 19, 2019 Online Published: December 26, 2019

doi:10.5430/jct.v9n1p1

URL: https://doi.org/10.5430/jct.v9n1p1

\begin{abstract}
The mass unemployment of the youth toady has mostly been attributed to the irrelevance of the school curriculum. However, the skills in the curriculum have not been subjected to critical analysis to empirically prove their relevance or otherwise. The purpose of the study was therefore to identify the skills embedded in the curriculum, those skills the learners have acquired and those that employers usually demand of employees by relating them to empirical findings of the skills employers in general demand of employees. A conceptual content analysis was used to determine the skills embedded in the curriculum. Purposive sampling procedure was used to select twenty-one students and fourteen key informants for an interview. The data from the interview were sorted out into themes and coded through the use of NVivo 8 to help in the counting of frequencies of each skill. It was found out that the senior high school curriculum, though was generally rated as relevant, the skills with the highest frequencies in the curriculum focused on attitudes and values while those required by employers focused on the application of knowledge. On the basis of these findings, it can be concluded that the curriculum is relevant in instilling values into the students but it is not relevant in the application of knowledge that employers usually demand of employees at the work environment.
\end{abstract}

Keywords: contextual reality, curricular relevance, relation, world of work, senior high school

\section{Introduction}

The senior high school is a terminating point for the majority of students and it turns out such school leavers without marketable skills to go into employment (Dzobo, 1987; Danso, 2018). Unemployment rate in Ghana is becoming alarming (Amankrah, 2014). It is a major concern because it makes one ponder on whether the curriculum contains the skills that make the learners of the curriculum critical thinkers, problem solvers, good communicators, good collaborators, information and technology literate, flexible and adaptable, innovative and creative, globally competent and financially literate (Partnership for 21st Century Skills, 2009; Chu, Tavares, \& Lee, 2017).). These concerns call for the question of the relevance of the senior high school curriculum. A curriculum that is relevant should relate to the contextual reality of the world of work. In other words, if students go through a curriculum and they want to work instead of furthering their education, they should be able to use the skills acquired so far to create their own jobs or to gain employment.

There are three strands succinctly stated in the senior high school curriculum. The first is that the curriculum contains enough knowledge and skills for students terminating their education at the end of the senior high school to gain employment. The second strand assures students of self-employment while the third strand enables them to further their education.

The realities on the ground in relation to graduating senior high students are that few are able to further their education while the majority of them, about $90 \%$, are "erroneously referred to as drop outs" (Ghana Education Service [GES], 2010) creating about $60 \%$ unemployment among the youth and thus making youth unemployment rate one of the highest (Amankrah, 2014). It is worthy of note that there have been several educational reforms and 
reviews in Ghana with the purpose of providing skills necessary for descent employment in industries, self-employment and pursuit of further studies (Ministry of Education [MOE], 2002). Research shows that only about $10 \%$ of school children passing through junior high school (JHS) to senior high school (SHS) gain admission to the universities with the remaining $90 \%$ being "erroneously referred to as dropouts" (MOE, 2002).

In an attempt to identify the underlining reasons for students' inability to gain employment, further their education or gain self-employment, contextual reality studies have been carried out on political influence (Otunga \& Nyandusi, 2013), cultural effects (Balarin \& Benavides, 2010), and socio-economics influence (Cornbleth, 1988). Some researchers have studied the skills requirements of students and the design of the curriculum (Anderson \& Gantz, 2013). Most of such studies looked at causes of unemployment without looking at the curriculum as a possible major cause (Ekwueme, Uchegbu, \& Nkemdirim, 2009).

This current study looked at the curriculum as a possible cause by looking at the relevance of the skills contained in it. Again, it explored the relationship between the skills in the senior high school curriculum and the skills that employers demand of employees. This study therefore sought to establish the skills in the curriculum, the relevance of such skills, and the skills that employers demand of employees. The present study is therefore guided by the following questions: 1) What kind of skills does the curriculum contain that could be imparted to the students to enable them to gain employment or go into self- employment? 2) What are the views of employers on the skills contained in the senior high school curriculum? 3) What do human resource experts in industries perceive to be the ideal work related skills that graduates of the senior high school require to enable them to gain employment or go into self-employment? 4) What is the level of skills that the students have acquired that will enable them to gain employment or go into self-employment?

\subsection{Skills in the Curriculum in Relation to Contextual Realities}

A lot of scholarly works on contextual realities have been carried out. One of the major studies on contextual realities was Jansen's (1988) Curriculum change and contextual realities: An analysis of recent trends in Black South African education. In this research, three projects - The Science Education Project (SEP), The Molteno Project (MP) and The Fort Hare Project (FHP) - were critically examined and evaluated. The purpose was to examine and evaluate the response of each intended change, through its planning and implementation, to the contextual realities.

The Science Education Project began in 1975 with the aim of improving science education. In view of this, practical work in terms of laboratory exercises were introduced into the science lessons in black schools (MacDonald, \& Rogan, 1985). The project was funded by the Anglo-American Corporation. The interest of the Corporation lied in the production of better quality manpower with the aim of reducing political tensions within the political arena (Jansen, 1988).

The findings showed that although practical work was prescribed in the syllabus, in general the closest pupils got to experimental work was reading about it in textbooks (Jansen, 1988; MacDonald \& Rogan, 1985). The project was therefore a complete failure.

Similar findings were revealed from the Molteno Project. It was revealed that contextual realities were not considered to any higher degree. The findings showed that contextual realities were considered only to the extent to which they served as a reference for technically efficient programmes (Jansen, 1988).

The Fort Hare Project was also a failure because there was a fundamental mismatch between the theoretical preparation of student teachers and the contextual realities of the school environment (Jansen, 1988; Millar, 1984). It was, therefore, advised that the relevance of acquired cognitive skills must be examined in relation to contextual realities. Again, any educational or curricular change in South Africa which has meaning to participants, and engages and empowers students in the critical transformation of contextual realities, will have to embody at least the following elements: a redefinition of educational goals, a reconstitution of educational relationships, a reinterpretation of African history, a reconstruction of curriculum content, and a reformulation of educational philosophy (Jansen, 1988).

\subsection{Skills Employers Demand of Employees}

One of the research works carried out on the skills that employers demand of employees was Barton's (2006) high school reform and work: facing labour market realities. The study was carried out in almost two decades. In this study, Barton reported on seven organisations: National Association of Manufacturers (NAM) (2001), Educational Quality of the Workforce National Employer Survey (1995), Department of Education Survey of 101 Executives (1988), The Committee for Economic Development Survey of Employers' Needs (1984), Conference Board Survey of Executives (1984), Centre for Social Organisation of Schools, The Johns Hopkins University (1984) and Survey 
on San Francisco Employers (1983).

The survey of the National Association of Manufacturers (2001) revealed that employers want well-rounded high school graduates who can read, write, calculate, solve problems, work in teams and have strong employability skills. Again, they want graduates familiar with the world of work and with varied career and post-secondary education options. They cited examples of reasons for rejecting applicants. The most frequently cited examples include inadequate employability skills, attendance, timeliness, and work ethics (69\%), followed by insufficient work experience $(34 \%)$ and failure to pass a drug screening test $(27 \%)$. The others, in the order of their ranks, were inadequate math skills, poor references from previous employers, oral communications, problem solving, and technical and computer skills.

Educational Quality of the Workforce National Employer survey also revealed attitudes and communications skills as the top priorities. These were followed by prior experience and recommendation information. According to the report, factors directly related to schooling appeared in the lowest level of the list though with younger workers education related skills may play a significant role.

The Department of Education Survey of 101 Executive survey also showed that ability to read and write together with computation, communication and problem solving skills were most required of applicants. The report recommended business leaders that schools should emphasise the importance of good habits such as self-discipline, reliability, perseverance, accepting responsibility and respect for the rights of others.

Among the most appealing skills in 500 large companies as well as 6,000 small companies of the Committee for Economic Development Survey of Employer Needs were striving to work well, learning how to learn, priority setting, and communicating. Both respondents indicated that the most desirable characteristics were difficult to find in young applicants.

In the survey of the Conference Board Survey of executives, the findings showed that employers were concerned with the observed inability of high school graduates to function effectively as communicators. The primary problem for the employers was attitude toward work and the workplace. The following, in an order of preference, were considered as very laudable: strong personal impression in interview, strong recommendation from manager in a firm who knows the candidate personally, strong letters of character reference, strong scores on a written test and strong school grades.

The findings from the survey of Personnel Officers, Centre for Social Organisation of Schools, The Johns Hopkins University, showed that academic factors ranked among the lowest on the list. What employers want were the same as those from the Conference Board Survey of Executives: strong personal impression in interview, strong recommendation from manager in a firm who knows the candidate personally, strong letters from previous employers, strong letters of character reference and strong scores on a written test.

The last of the survey, San Francisco Employers, revealed that employers looked up for applicants that seemed serious about work and eager to get the job; those who seemed bright and alert, courteous and personable, who seemed to have the ability to learn quickly, who had a neat appearance and appropriate dress, good reading ability and good ability with numbers, and the least they looked up for was a record of achievement in school.

The seven organisations revealed a lot of skills that employers require of employees. There are, however, a lot of commonality on what employers require of applicants. Those important and common skills that ran through the various surveys were attitudes, first impressions and recommendations.

Even though there were some lapses in the survey, the primary focus of the study of identifying a set of employability skills employers require of employees was achieved. These types of skills are referred to as "soft skills." The research conducted by Rosenbaum (2005), however, showed that although soft skills are often employers' highest priority, they are rarely taught in high schools or colleges. This resulted in the 'school achieving' to have been listed among the lowest skills required of employees. A research conducted by Carnevale and Hanson (2015) also showed that students who do best in high school also do best on the job, but the match between the academic content in high school and the subsequent knowledge required on the job is not significant.

\subsection{The Teaching Syllabi of the Senior High School Curriculum}

A syllabus is an organising document in the area of instruction (Chandler, 1985). It is a vehicle by which organisation and structure of intended learnings are communicated from teacher to teacher and teacher to learner (Eash, 1991). Each of the syllabi of the seven programmes of the senior high school is an official document designed by National Council for Curriculum and Assessment ( $\mathrm{NaCCA}$ ), formerly by the Curriculum Research and 
Development Division (CRDD), under the auspices of the Ghana Education Service (GES) of the Ministry of Education (MoE). After the design of the syllabus, it is handed over to the classroom teacher for implementation.

The seven programmes are Agricultural, Business, Technical Drawing, General Science, General Arts, Home Economics and Visual Arts programmes. The Agriculture programme comprises five major areas with detailed syllabus of each. These are the General Agriculture, Crop Husbandry and Horticulture, Animal Husbandry, Fisheries and Forestry. The Business programme comprises Business Management, Cost Accounting, Typewriting, Clerical Office Duties and Financial Accounting. The time allocation is the same for all the courses. The Technical programme is composed of seven subjects - Applied Electricity, Auto Mechanics, Building Construction, Electronics, Metal Works, Technical Drawing and Wood Work. The General Arts programme comprises a lot of subjects. These include Christian Religious Studies, French, Geography, Ghanaian Languages, Government, History, Islamic Religious Studies, Literature in English, Economics and West African Traditional Religion. The Visual Arts programme comprises nine subjects. They include Basketry, Ceramics, General Knowledge in Art, Graphic Design, Jewellery, Leather Work, Picture making, Sculpture and Textiles. The subjects that make up the Home Economics programme are Clothing and Textile, Food and Nutrition and Management in Living. The General Science programme comprises Chemistry, Elective Biology, Elective Physics and Elective Maths.

The structure of the various syllabi is similar - the general aims, scope of content to be covered, time allocation, suggestions for teaching the syllabi, practical skills, detailed content and materials or equipment needed for teaching and learning. Each of the syllabi has both theory and practical component, has 6 periods of 40 minutes per week and out of the six periods, three are devoted to practical work and three to theory. Thirdly, each has two strands providing terminal education for students or serving as a prerequisite for further studies. This strand is summarised using a sample from General Agriculture:

The content of this syllabus has been designed in a way that will offer knowledge and skills to students for whom Senior High School education is terminal. Knowledge and practices acquired in this subject will enable such students to work on their own, or seek employment in agricultural establishments. The syllabus also provides adequate foundation knowledge and skills for students who will want to pursue further education and training in agriculture after SHS (GES, 2010).

\subsection{The Core Subjects.}

The core subjects make each programme complete and there are five of them: English Language, Mathematics, Integrated Science, Social Studies and Information and Communications Technology (ICT). The core subjects also have the same organisational pattern and structure. The major difference can be found in the area of the profile dimensions. For example, while in ICT knowledge and understanding has $10 \%$, application of knowledge is $30 \%$ and practical skills give $40 \%$, the percentage values in Mathematics are 30\% for knowledge and understanding and $70 \%$ for application of knowledge. English language has knowledge and understanding and the application of knowledge as $40 \%$ and $60 \%$ respectively. The remaining two also vary. Integrated Science, for instance has $20 \%$ for knowledge and understanding, $40 \%$ for application and $40 \%$ for practical and experiential skills but those of Social Studies are $35 \%$ for knowledge and understanding, $40 \%$ for the application of knowledge and $25 \%$ for attitudes and values.

\section{Method}

\subsection{Study Area}

Any of the senior high schools in the country could be selected for the study. However, one endowed senior high school that was offering all the seven elective programmes was selected for the study. There were four senior high schools in the country at the time of the research that fell within the best schools by Ghana Education Service (GES) (2014) criteria which offered all the seven programmes. These schools were Baidoo Bonso Senior High/Technical at the Ahanta West District in the Western Region, Mawuli Senior High School in Ho District in the Volta Region, Keta Senior High School in Keta District in the Volta Region and Tamale Senior High School in Tamale Metro District in the Northern Region.

Based on the GES (2014) criteria for school selection, Mawuli was among the four schools that offered all the seven programmes of the senior high school. Mawuli Senior High School was, therefore, chosen as the study area since it was purported to have provided the relevant data. Creswell (2014) states that purposive sampling is used in so far as it is a good example of what is being studied and so far as it will provide the necessary data as required. 


\subsection{Research Design}

The study's paradigm was social constructivism so qualitative approach was used and in particular a case study. The qualitative research approach was supported with theoretical propositions. The study used a descriptive single case design. The rationale for using this design was that the study sought to look at a phenomenon in its real-life context (case study) (Robson \& McCartan, 2016); it is also meant to give a narrative account of it (descriptive) (Merriam, 2001; Yin, 2002); finally, it sought to provide in-depth investigation and rich description (Darke, Shanks \& Broadbent, 1998).

The target population of the study comprised all final year students of Mawuli senior high school in Ghana. It also included some selected resource personnel of various industries in Ghana. This constitutes the sample frame from which the sample was selected. In all, twenty one students (3 each of the 7 programmes) were interviewed. This constituted those in the excellent position, average position and low performing position. The human resource personnel, fourteen in number from industries or from the world of work - fishing industry, estate farm (Agriculture); Centre for Scientific Medical Research and Science Department of a university (Science); Agorwu Furniture and Alizoo Entreprise (Technical Drawing); Business Department of a university and Finance Sector at Centre for Scientific Medical Research (Business); Pentecost Press and Physical Plant Department (General Arts); Pentecost Press (Visual Arts); Catering Services of a university and Forest Hotel, Ghana (Home Economics) - were selected for interview based on the related careers. They were also selected from both the formal and informal sectors of the economy. So in all, the researchers selected thirty five personalities for an interview. In addition to this, content analysis of the curriculum was also done.

\subsection{Unit of Analysis}

The problem under investigation was to find out the prospects of graduating senior high school students of a curriculum in relation to employment. The study therefore sought to find out the relevance of such a curriculum. Four research questions were used to guide the study. These four research questions "determine the appropriate unit of analysis and number of cases" (Darke, Shanks \& Broadbent, 1998). The four research questions provided four units of analysis, hence four single cases. For example, 1) the first unit of analysis was the content analysis to identify the skills contained thereof in the curriculum. 2) The human resource personnel's assessment of the skills in the curriculum could determine the relevance of the school curriculum. 3) The level of acquisition of skills by the students. 4) Human resource personnel from industries could also identify the required work related skills or employable skills so they constituted another unit of analysis. In all, there were four units of analysis with the corresponding four single cases.

\subsection{Data Collection Instruments}

Two instruments of data collection, interview guide and theme generating guide of content analysis, were used to gather data from the informants. The interview guide, as an instrument, was used because it served as a dynamic guide for conversation (Marrie-Lou, Christiane \& Jorgen, 2011). A theme generating guide of content analysis of the senior high school curriculum was also used because there was the need to establish the number and nature of skills embedded in the curriculum.

\subsubsection{Data Collection Procedure}

The purpose of the study required that the senior high school curriculum be analysed in order to determine the skills embedded in it. It also required the identification of the skills employers usually require of employees.

In the content analysis of the senior high school curriculum, the syllabus of each of the seven programmes Agriculture, General Science, Technical Drawing, Business, General Arts, Visual Arts and Home Economics - were analysed with the help of NVivo 8. The general objectives of the various syllabi that contained the skills were then scrutinised to help ascertain the various skills.

The frequency of the various skills of each syllabus was established. This helped to determine the most common skills and the major focus of emphasis. The skills were compared with the skills that employers usually require of employees.

The interview for data collection from students was structured and situated within the framework of Seidman's (2013) phenomenological interview methodology. This method focuses on three interviews of the participant's experience with the phenomenon: focused life history (experiences that preceded the participant's experience with the phenomenon), details of the experience and reflection on meaning.

During the data collection, the researchers went to the school personally to interview the students. They first of all 
sought permission from the Headmaster of the institution. The Headmaster then made the subject tutors assist us by organising the students for the interview. The interview of the students was of two parts. The first part took the students through their preconceived ideologies before entry into the senior high school, their practical transaction with the school curriculum and their future perspectives. The three students for each programme were interviewed together, making it a focused group interview. A question would be posed them and each had an equal opportunity to respond. The researchers were preparing notes out of their responses and at the same time recording the interview. The second part was the assessment of the industrial personnel. The skills from the curriculum were itemised and the personnel were to assess them in terms of their relevance.

\subsection{Theoretical Propositions}

Theoretical propositions are statements based on the skills embedded in the curriculum, employers' rating of the skills, the skills employers usually demand of employees and the students' level of acquisition of the skills. These are outlined in Table 1.

Table 1. Theoretical Propositions

\begin{tabular}{c}
\hline Theoretical Propositions of the Relevance of the Senior High School Curriculum \\
\hline Skills embedded in the curriculum \\
2 The skills in the curriculum with the highest frequencies are an embodiment of the application of knowledge \\
3 The skills in the curriculum with the highest frequencies are basically within the affective domain
\end{tabular}

$$
\text { Employers' rating of the skills in the curriculum }
$$

4 Employers rate all the skills in the curriculum as relevant

5 The first ten highest frequencies of skills that employers rate of the skills in the curriculum are the same first ten highest frequencies of skills that emerge in the curriculum

The skills employers demand of employees and the skills in the curriculum

6 The skills in the curriculum are the same skills that employers demand of students for employment.

Students' acquisition of skills

7 The students have acquired most of the skills to enable them to gain employment or go into self-employment.

Source: Researcher's construct

\subsection{Data Analysis}

Data obtained from content analysis of the senior high school curriculum were analysed with the help of NVivo 8 . The skills contained in the general objectives of the curriculum were identified and through the NVivo, an open coding of the skills was used to categorise them. The category of the skills was followed by the identification of themes (cognitive, affective \& psychomotor) and the use of Tree nodes for sub-themes. A final coding of the skills helped in the counting of frequencies. A simple statistical analysis (Microsoft Office Excel) for visual representations - tables and graphics - was also used (Anderson \& Aresenault, 2005). In the case of the closed quantitative interview of students, a scale was used to rate the level of students' familiarity with the identifiable skills in the curriculum. Statistical analysis using Microsoft Office Excel was adopted. This procedure of coding the skills was the same for the analysis of the data from employers. The theoretical propositions were also analysed by comparing and contrasting them with the empirical data and this helped to reject or fail to reject the propositions.

\section{Results}

\subsection{Responses to Research Questions}

Research Question One: What skills does the curriculum contain that could be imparted to the students to enable them gain employment or go into self-employment? In response to this research question, content analysis of the senior high school curriculum was done and this helped to ascertain the skills contained in the curriculum. 


\subsection{Generic Skills of all the Seven Programmes}

The skills of each programme were identified through conceptual analysis and with the help of NVivo 8. Those skills totalling five and above were put together in Table 2 . Those skills totalling below five were not included in the table. In all, 58 skills were identified with a total frequency of 1,444 representing $100 \%$. Nine of the skills ranged between $3.04 \%$ and $18.52 \%$ and these served as the most common skills. These skills included, from the highest to the lowest, appreciation $268(18.52 \%)$; skills of understanding $230(15.89 \%)$; skills of recognising $186(12.85 \%)$; skills of awareness 158 (10.92\%); skills of acquisition $103(7.12 \%)$; skills of development 94 (6.50\%); skills of application 51 (3.52\%); skills of description 3.18\%) and the skills of speech/communication 44 (3.045\%). These nine common skills represent $75.33 \%$ skills. The remaining $49(24.67 \%)$ skills fell below $3 \%$. The frequency of the skills per programme is shown in Table 2 .

Table 2. Generic Skills of all the Seven Programmes

\begin{tabular}{|c|c|c|c|c|c|c|c|c|}
\hline \multirow[b]{2}{*}{ Skills } & \multicolumn{8}{|c|}{ frequency of skills per programme } \\
\hline & Agric. & Science & Techni. & Busi & $\begin{array}{c}\text { General } \\
\text { Arts }\end{array}$ & $\begin{array}{c}\text { Visual } \\
\text { Arts }\end{array}$ & $\begin{array}{l}\text { Home } \\
\text { Econs }\end{array}$ & Total \\
\hline Appreciation & 51 & 47 & 31 & 61 & 31 & 32 & 15 & 268 \\
\hline Understanding & 22 & 36 & 13 & 43 & 39 & 55 & 22 & 230 \\
\hline Recognisance & 50 & 36 & 24 & 22 & 12 & 14 & 28 & 186 \\
\hline Awareness & 42 & 19 & 17 & 33 & 11 & 21 & 15 & 158 \\
\hline Acquisition & 12 & 01 & 26 & 28 & 14 & 16 & 06 & 103 \\
\hline Development & 05 & 02 & 07 & 30 & 01 & 36 & 13 & 094 \\
\hline Application & 07 & 17 & 18 & 00 & 03 & 04 & 05 & 054 \\
\hline Description & 02 & 01 & 00 & 00 & 21 & 00 & 22 & 046 \\
\hline Speech & 00 & 00 & 00 & 00 & 22 & 00 & 22 & 044 \\
\hline Utilisation/using & 05 & 13 & 10 & 00 & 00 & 00 & 03 & 031 \\
\hline Ability & 00 & 02 & 01 & 01 & 10 & 03 & 10 & 027 \\
\hline Exposure & 00 & 00 & 00 & 00 & 05 & 03 & 05 & 013 \\
\hline Communication & 01 & 01 & 00 & 00 & 05 & 00 & 06 & 013 \\
\hline Explanation & 00 & 02 & 02 & 00 & 04 & 00 & 04 & 012 \\
\hline Finding & 00 & 06 & 06 & 00 & 00 & 00 & 00 & 012 \\
\hline Identification & 02 & 02 & 00 & 03 & 01 & 03 & 01 & 012 \\
\hline Expression & 00 & 00 & 00 & 00 & 05 & 00 & 05 & 010 \\
\hline Summary & 00 & 00 & 00 & 00 & 05 & 00 & 05 & 010 \\
\hline Asking \& ans. & 00 & 00 & 00 & 00 & 05 & 00 & 05 & 010 \\
\hline Showing & 03 & 03 & 00 & 00 & 00 & 00 & 03 & 009 \\
\hline Demonstration & 04 & 00 & 00 & 00 & 00 & 00 & 03 & 007 \\
\hline Distinguishing & 00 & 04 & 03 & 00 & 00 & 00 & 00 & 007 \\
\hline Calculation & 00 & 03 & 03 & 00 & 00 & 00 & 00 & 006 \\
\hline Determining & 01 & 02 & 02 & 00 & 00 & 00 & 01 & 006 \\
\hline Resolution & 00 & 03 & 03 & 00 & 00 & 00 & 00 & 006 \\
\hline Restructure & 00 & 00 & 00 & 00 & 03 & 00 & 03 & 006 \\
\hline Relation & 01 & 03 & 01 & 00 & 00 & 00 & 00 & 005 \\
\hline Total & 222 & 217 & 175 & 225 & 200 & 188 & 217 & 1444 \\
\hline
\end{tabular}

Source: Researcher's construct 
The frequency of all the skills of the seven programmes, as presented in Table 2, is graphically represented in Figure 1 with the first ten highest skills. The skills in their order of value in terms of frequency are the skills of appreciation, understanding, recognition, awareness, acquisition and development, with application, description, speech and utilisation being the lowest in frequency.

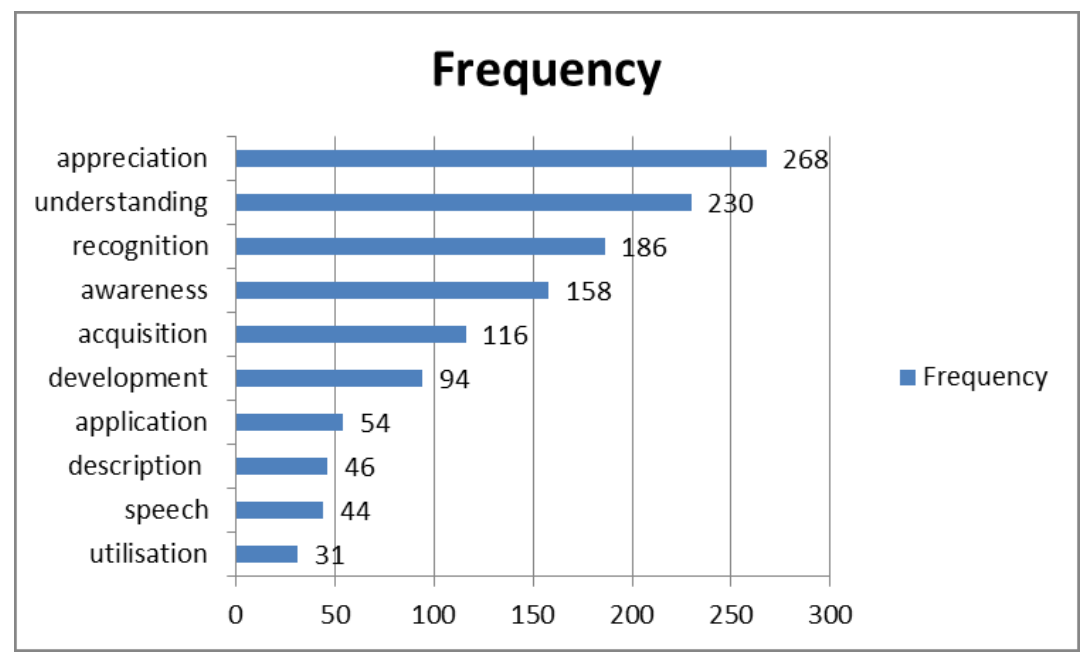

Figure 1. The First Ten Skills with the Highest Frequency of all the Seven Programmes

\subsection{Frequency of Skills of the Core Subjects}

The frequency of skills of the core subjects was added to the frequency of skills of all the seven programmes. The total number of skills of the core subjects was 56 with a total frequency of 178 . The order of value of the frequencies as they featured in all the seven programmes has not changed with the addition of the skills from the core subjects.

From the above discussion it could be realised that the 10 most common skills from the senior high school curriculum, the skills with more than 30 frequencies, from their order of value, were the skills of appreciation 283 (17.4\%); skills of understanding 241 (14.8\%); skills of recognition $207(12.7 \%)$; skills of awareness $170(10.4 \%)$; skills of acquisition $116(7.1 \%)$; skills of development $107(6.5 \%)$; skills of application 58(3.6\%); skills of speech/communication 55 (3.4\%); skills of description 46 (2.8\%) and skills of utilisation/using 40 (2.5\%).

The senior high school curriculum, in sum, contains 56 skills of the core subjects with a total frequency of 178; it also reveals a total of 58 skills of all the seven programmes with a total frequency of 1,444 . The overall number of skills contained in the senior high school curriculum reads 114 with an overall frequency of 1,622.

\subsection{Theoretical Propositions 1,2 and 3}

1. The skills in the curriculum with the highest frequencies are an embodiment of the application of knowledge.

2. The skills in the curriculum with the highest frequencies are basically within the affective domain.

3. The skills in the curriculum with the highest frequencies are basically within the psychomotor domain.

The first five skills with the highest frequencies constitute skills of affective domain, particularly skills of valuing. These five skills have a frequency value of 1,017 as against a frequency value of 306 of the cognitive skills of development, application, speech, description and utilisation. It can be concluded that the senior high school curriculum focuses on the skills of the affective domain, particularly skills of valuing. None of the skills falls under the psychomotor domain. The implication is that even the skills in the vocational oriented subjects do not have much emphasis. Also, the skills in the cognitive domain which focus on knowledge, comprehension, application, analysis, synthesis and evaluation do not have any major place in the curriculum. On the basis of these findings, theoretical propositions two and three are rejected while proposition one fails to reject.

Research Question Two: What are the views of employers on the skills contained in the senior high school curriculum?

In order to ascertain the views of employers about the relevance of the senior high school curriculum, the selected employers were asked to rate the skills in the curriculum. They were also asked to establish the similarities between 
the first ten skills with the highest frequency in the curriculum and those first ten skills with the highest frequency that employers have rated of the curriculum. In each of these two processes fourteen personnel were interviewed.

In order to determine the relevance of such skills, the employers were asked to rate them. An interview schedule was used. In this interview schedule, a closed quantitative interview was adopted. In a closed quantitative interview, "questions and response categories are determined in advance. Responses are fixed; respondent chooses from among these fixed responses." (Patton, 1980). A rating scale of skills not required [0], skills less required [1], skills required [2], skills mostly required [3] and skills highly required [4], at work places was used. Cohen, Manion and Morrison (2011) opine that the use of this technique along with open-ended questions is a comparatively recent development and means that scale scores can be checked against data elicited by the open-ended questions. The use of the rank scale was to help in responding to the theoretical proposition 4 :

Theoretical proposition 4: Employers rate all the skills in the curriculum as relevant.

The rating scale of skills not required [0], skills less required [1], skills required [2], skills mostly required [3] and skills highly required [4] was used and the analysis of the data revealed that there was none of the skills that was rated as 'Not Required.' All the skills in the curriculum were either less required, required, mostly required or highly required. Apart from three out of the fourteen organisations which rated the skills with a frequency of $36(45 \%), 65$ $(48 \%)$ and $67(49 \%)$ for General Arts, Visual Arts and Home Economics respectively, the remaining eleven organisations rated the skills beyond $50 \%$.

The higher the frequency, the higher the skills are required. For instance, one Doctor at the Centre for Scientific Research into Plant Medicine rated the skills in the Science programme as high as $122(90 \%)$ out of $136(100 \%)$. This is what the Doctor said when he was asked whether the skills in the curriculum might be required or considered for employment:

You see, anything science is high. Any, you see our scientific disciplines are varied and many so anything science is high. I said because we do different scientific disciplines - we have biological related, agricultural related, chemistry related - so all these science related skills, we rate them very high.

To be frank with you even junior high school syllabus, the kind of things that is there, their science syllabus, the sort of skills or content that is there, if they take time to teach and understand it very well, they are very very valuable; you see but it's just a rush. The students pass through and come out as if they have not learnt anything. You see, but the kind of things that is with the junior high school science syllabus is a lot.

On the question of unemployment of senior high school graduates, the Doctor lamented bitterly as:

We need to put politics out of education and leave education for educationists and technocrats. You see, when we do that it will help a lot. It is the rush. It is the rush. It is rush and then also, you know a lot of people pass the senior high school examination and only a few get the opportunity to go to the university.

A lot of people who go to the university, only a few of them get the courses they want to pursue and because of that the major emphasis of the senior high school programme is just to pass the exam in order to get the course you want to pursue at the university. If we have a lot of universities, especially public universities where we don't pay as much as the private ones so that students have a lot of options, there wouldn't be so much emphasis on getting certain grades in order to get certain course; that will relieve the pressure.

You see, what is happening is that even if you make the senior high school four years and you introduce even more practical courses, the students will emphasise the theory because they are targeting certain courses at the university.

Some of the employers also rated the skills as 'less required.' According to them, it was not because of the irrelevance of the skills but because the skills seem to be above the students' level so they would not be able to apply them. For example, an Accountant at the Centre for Scientific Research into Plant Medicine noted:

You see, they rush them through the course. For example, I know for those who do accounting, costing; it is almost like the A'level or O'level. Some of these skills may be less required because the skills seem to be beyond their capabilities. For example, "recognition of the social, ethical and legal responsibilities" is beyond their capabilities. The syllabus is detailed and the child cannot get the knitty gritty of all these so it is like chew, pour and forget. So, when they finish and come out they don't know practically anything as compared to those who were offering the O'level and A'level. But these senior high graduates when they come they are given every explanation yet they don't understand.

The Human Resources Manager at the Pentecost Press commented on the curriculum as follows: 
Generally, the skills are very important because they can be applied at the work place. If only they have time to learn all these. But the students come out as if they have not learnt enough. These skills seem to be more detailed than the previous ones, for example, during our times. So in short I will say that the skills are okay, they are relevant.

Similar comments about the detailed nature of the curriculum were made by many of the employers. The major problem they observed was that the students are usually rushed through the curriculum; hence, they are not able to grasp those detailed skills embedded in the curriculum. It can therefore be concluded that the skills in the curriculum are relevant hence the senior high school curriculum is relevant. Thus, the employers rate the skills in the curriculum as relevant. The theoretical proposition 4 , therefore fails to reject.

Theoretical Proposition 5: The first ten highest frequencies of skills that employers rate of the skills in the curriculum are the same first ten highest frequencies of skills that emerge in the curriculum.

The second major aspect of employers' rating of the skills in the curriculum was to find out the similarities between the skills that have the highest frequencies in the curriculum and those that employers have rated as the highest. The content analysis of the curriculum in order to determine the skills with the highest frequencies revealed the following skills in their order of value: skills of appreciation, understanding, recognition, awareness, acquisition, development, application, description, communication and utilisation.

The employers who were interviewed also indicated the skills that they required 'less, most or high.' The first ten highest skills of each programme were rated and the following were the frequencies employers highly require and they are in their order of value: Skills of application, identification, appreciation, drawing, ability, acquisition, awareness, development, understanding and communication.

In comparing the two, it was realised that three of the skills with the highest frequencies in the curriculum - skills of recognition, description and utilisation - cannot be found in the skills that the employers have rated as the highest. Again, three of the skills that the employers have rated as the highest - skills of identification, drawing and ability cannot also be found in the skills that have the highest frequencies in the curriculum. The rest of the skills in the curriculum and those that employers have rated as the highest can be identified.

One interesting revelation, however, is that the order of importance of the skills in the curriculum is not the same order of importance for employers. For instance, the skill with the highest frequency in the curriculum, the skill of appreciation, appears as the third highest in the rank order by employers. Again, the second skill with the highest frequency, the skill of understanding, appears as the ninth highest in the rank order; the rest are as follows: the skill of awareness at the fourth position appears at the seventh position; the skill of acquisition at the fifth position appears at the sixth position, etc.

Another revelation is that while the skills with the highest frequencies in the curriculum, especially the first four, appreciation, understanding, recognition and awareness - are non-practical in nature, those that the employers rate as the highest, especially the first two and the third one, - application, identification and drawing - are more of practical in nature. Taking into consideration the differences in the order of importance of the skills with the highest frequencies, those with non-practical direction and those with practical orientation, it can be concluded that, though the employers have rated all the skills in the curriculum as important, those skills in the curriculum in terms of the order of importance are not in the same order of importance as rated by the employers. In sum, the skills in the curriculum with the highest frequencies are not the same skills with the highest frequencies that employers require.

Research Question Three: What do human resource experts in industries perceive to be the ideal work related skills that graduates of the senior high school require to enable them to gain employment or go into self-employment?

In response to this research question, the fourteen selected employers were interviewed to ascertain the skills that employers require of employees. In all, there were one hundred and eighty two (182) skills: Agriculture (31), Science (33), Technical Drawing (21), Business (24), General Arts (29), Visual Arts (18) and Home Economics (26). The first ten highest skills revealed practical approach to issues in an organization. These are the skills that employers highly required of employees. This was followed by communication, appearance, commitment, etc.

All the skills that the employers gave out were screened through Bloom's (1956), Krathwohl et al.'s (1964) and Harrow's (1972) taxonomies: Cognitive, Affective and Psychomotor, respectively. While the cognitive domain focuses on the application of knowledge, the affective domain is concerned with valuing. The psychomotor domain also concerns with skilled behaviour (Reeves, 2006). The various skills that the employers gave out were screened through these domains. They constituted the themes of the skills and through "Tree nodes" the sub-themes were counted. The frequencies of each sub-theme under each programme are illustrated in Table 3 below. 
Table 3. Skills Employers Demand of Employees

\begin{tabular}{|c|c|c|c|c|c|c|c|c|}
\hline \multirow{2}{*}{ Skills } & \multicolumn{8}{|c|}{ Interview of Employers in Respective Programmes } \\
\hline & Agric & Sci & Tech. & Busi. & G. Arts & V. Arts & H. Econs & Total \\
\hline \multicolumn{9}{|l|}{ Cognitive } \\
\hline Knowledge & 03 & 01 & 02 & 02 & 00 & 02 & 03 & 13 \\
\hline Comprehen. & 06 & 06 & 03 & 03 & 04 & 02 & 07 & 31 \\
\hline Application & 06 & 03 & 02 & 04 & 11 & 02 & 04 & 32 \\
\hline Analysis & 02 & 01 & 00 & 00 & 04 & 00 & 01 & 08 \\
\hline Synthesis & 01 & 04 & 04 & 04 & 01 & 00 & 03 & 17 \\
\hline Evaluation & 02 & 00 & 02 & 03 & 00 & 00 & 00 & 07 \\
\hline \multicolumn{9}{|l|}{ Affective } \\
\hline Receiving & 00 & 01 & 00 & 00 & 00 & 00 & 00 & 01 \\
\hline Responding & 01 & 02 & 02 & 01 & 02 & 00 & 01 & 09 \\
\hline Valuing & 02 & 06 & 00 & 01 & 01 & 05 & 02 & 17 \\
\hline Organisation & 00 & 01 & 00 & 00 & 00 & 00 & 02 & 03 \\
\hline Characterisat. & 07 & 07 & 05 & 03 & 04 & 05 & 02 & 33 \\
\hline \multicolumn{9}{|l|}{ Psychomotor } \\
\hline Reflexive & 00 & 00 & 00 & 00 & 00 & 00 & 00 & 00 \\
\hline Fundamental & 00 & 00 & 00 & 00 & 00 & 00 & 00 & 00 \\
\hline Percept, ability & 00 & 00 & 00 & 00 & 00 & 00 & 00 & 00 \\
\hline Physic. abilities & 01 & 01 & 00 & 00 & 00 & 00 & 01 & 03 \\
\hline Skilled mov't & 00 & 00 & 01 & 03 & 02 & 02 & 00 & 08 \\
\hline Expressi. mov't & 00 & 00 & 00 & 00 & 00 & 00 & 00 & 00 \\
\hline Non-discriminat & 00 & 00 & 00 & 00 & 00 & 00 & 00 & 00 \\
\hline Total & 31 & 33 & 21 & 24 & 29 & 18 & 26 & 182 \\
\hline
\end{tabular}

Source: Researcher's construct

The total number of skills that the employers who were interviewed posited to be mostly required at work places was one hundred and eighty two (182). Each programme has its own number of frequencies as indicated in Table 3. Five of the highest skills constitute the skills of the Affective domain: Characterisation, valuing, responding, organisation and receiving. Six of the skills are subsumed under cognitive domain: application, comprehension, synthesis, knowledge, analysis and evaluation, in their order of value. The rest of the skills fall under psychomotor domain: skilled and physical movements. In all, the affective domain contains a frequency of 63 while the cognitive domain comprises a frequency of 108 with the psychomotor domain consisting of a frequency of eleven (11). It can, therefore, be concluded that employers demand more of the skills that relate to cognitive domain.

Theoretical Proposition 6: The skills in the curriculum are the same skills that employers demand of employees for employment.

The conceptual analysis of the curriculum revealed a lot of skills but the first eleven skills with the highest frequencies included appreciation, understanding, recognition, awareness, acquisition and ability (affective domain) (1,017 frequencies) and development, application, speech, description and utilisation (cognitive domain) (306 frequencies). The senior high school curriculum lays emphasis on the skills of the affective domain. It can be stated categorically that the curriculum emphasises skills of the affective domain since the first five highest skills fall under the affective domain and in all, 1,017 frequencies of affective domain as against 306 frequencies of the cognitive domain.

The interview with employers revealed that eight skills - practical approach, creativity, planning and computing (application of knowledge), communication (comprehensive), analysis (analysis) and knowledge and intelligence (knowledge) - in their order of value, fall within the cognitive domain. Commitment, interpersonal relations and understanding are affective in nature. The rest - writing and design - are psychomotor skills, and specifically skilled abilities.

It can be deduced from the analysis that while the senior high school curriculum recommends skills of the affective domain, mostly skills relating to valuing, employers require cognitive skills and mostly skills of application of knowledge. It can be concluded that the skills in the curriculum are not the same skills that employers require of 
graduating senior high school students, even though the skills in the curriculum have been rated as relevant.

Research Question 4: What is the level of students' acquisition of skills in the curriculum that will enable them to gain employment or go into self-employment?

The percentage value of the total frequencies that the students have acquired (4870) against the total frequencies in the curriculum (7680), (based on the rank scale), is 63.4. This shows that the students have acquired quite above average of the skills contained in the curriculum. It also implies that as the curriculum is adjudged relevant then the students are well equipped with the necessary skills to go into the world of work. It has been revealed that students offering Home Economics programme have acquired most of the skills in the curriculum followed by those in Science, even though one student acquired less than average in Science. Agricultural programme is the third followed by those in the Technical Drawing and the General Arts programmes with the least being Business and Visual Arts programmes.

\section{Discussion}

The analysis of the generic skills of all the programmes revealed that the most common skills that have the highest frequency and that cut across all the programmes are the skills of appreciation 268 (18.52\%); skills of recognition $186(12.85 \%)$ and the skills of awareness $158(10.92 \%)$. These same skills appeared as the highest in frequency in the Agricultural programme. For instance, skills of appreciation had frequency of $51(22.97 \%)$ with the skills of recognisance having the frequency of $50(22.52 \%)$ and that of the skills of awareness being $42(18.92 \%)$. Apart from the skills of understanding that had a frequency of $22(9.91 \%)$ the rest of the skills fell below $6 \%$.

In the Science programme, the three skills - appreciation, recognition and awareness - as observed in the Agricultural programme - were still high as compared to the other skills in the Science programme. For instance, skills of appreciation had a frequency of $47(21.66 \%)$ with the skills of recognition having a frequency of $36(16.59 \%)$ while the skills of awareness 19 (8.76\%) fell below those of Agricultural programme.

In the case of the generic skills for the Technical Drawing programme, the skills of appreciation still stood out with the frequency of $31(17.71)$; the skills of acquisition $26(14.86 \%)$, however, supersede those of the skills of recognition $24(13.71 \%)$. Again, the skills of application 18 (10.29\%) are higher than those of awareness 17 (9.71\%). There is therefore a little shift of emphasis on the skills perhaps due to the technical nature of the Technical Drawing programme.

An observation of the Business programme also revealed that the skills of appreciation 61 (27.11\%) were outstanding. There was a shift from the emphasis on the skills of awareness $33(14.67 \%)$ and recognition $22(9.78 \%)$ to the skills of understanding $43(19.11 \%)$. Even the skills of development $30(13.32 \%)$ and the skills of acquisition 28 (12.44\%) superseded those skills of recognition 22 (12.44\%).

In the General Arts programme, it was rather the skills of understanding $39(19.60 \%)$ that stood out. These skills were followed by those skills of appreciation 31 (15.58\%). Communication skills $22(11.06 \%)$ were next of the continuum with skills of description $21(10.55 \%)$ following. Those skills of recognisance $12(6.03 \%)$ and awareness $11(5.52 \%)$ playing significant roles in the Agricultural, Science and Technical Drawing programmes were less recognised in the General Arts programme.

There is a significant shift of emphasis on skills in the Visual Arts programme. The most outstanding skills are those of the skills of understanding $55(29.26 \%)$. These were followed by the skills of development $36(19.15 \%)$. The skills of appreciation $32(17.02 \%)$ and those of awareness $21(11.17 \%)$ still had a major role to play in the Visual Arts programme though not as recognised as in the Agricultural, Technical and Science programmes. The two other recognisable skills were those of acquisition $16(8.51 \%)$ and recognition $14(7.45 \%)$.

A critical observation of the Home Economic programme revealed yet another drastic shift in the emphasis of skills. The skills of recognition $28(12.90 \%)$, though among the prevalence of skills noticed in the Agricultural, Science and Technical programmes, was outstanding. Instead of the skills of awareness $15(6.91 \%)$ and appreciation $15(6.91 \%)$ coming next to the skills of recognisance, those skills of description $22(10.14 \%)$, acquisition $22(10.14 \%)$ and speech/communication $22(10.14 \%)$ of the same values came next.

In the analysis of the skills that employers require of employees, it was revealed that the affective domain contained a frequency of 63 while the cognitive domain comprised a frequency of 108 and the psychomotor domain consisted of a frequency of eleven (11). The skills of the cognitive domain are more than those of the affective and psychomotor domain. Since the skills of the cognitive domain deal more with the application of knowledge, it can be 
concluded that employers demand more of the skills that relate to the application of knowledge.

\section{Conclusion}

Through the conceptual analysis of the senior high school curriculum, it was found out that there were 56 skills in the core subjects [English Language, Mathematics, Integrated Science, Social Studies and Information and Communications Technology] with a total frequency of 178. All the seven programmes contained 58 skills with a total frequency of one thousand, four hundred and forty-four (1444). In all therefore, there were one hundred and fourteen (114) skills in the senior high school curriculum and this figure represented a total frequency of one thousand six hundred and twenty-two $(1,622)$.

The employers rated the skills in the curriculum and it was revealed that all the skills contained in the curriculum were required at the work place though with different degree of requirements. The broad-based nature of the skills and the employers' acceptance of the skills in the curriculum showed that the skills in the curriculum were more of cross-functional skills than occupation specific skills even though both cross-functional and occupation specific skills were contained in the curriculum. Apart from three organisations (out of the fourteen organisations) that rated the skills in the curriculum with a frequency of $36(45 \%), 65$ (48\%) and $67(49 \%)$ for General Arts, Visual Arts and Home Economics respectively, the remaining eleven organisations rated the skills in the curriculum beyond 50\%. This showed that the skills in the curriculum were relevant hence the senior high school curriculum was relevant.

The study revealed that the skills in the curriculum were mostly within the affective domain as against the cognitive and psychomotor domains. This finding corroborated with Barton's (2006) findings from the seven organisations. The common skills found in the seven organisations were basically within the affective domain.

It was noted that while the senior high school curriculum recommended skills of the affective domain, mostly skills relating to valuing, employers required cognitive skills, mostly skills of the application of knowledge. Empirical evidence is in support of the affective skills but employers interviewed were in support of skills within the affective domain.

\section{References}

Amankrah, J. Y. (2014). Youth unemployment in Ghana: Prospects and challenges. Ghana Statistical Service. Retrieved from www.upa.org.gh/researchpapers/youth73

Anderson, C., \& Gantz, J. F. (2013). Skills requirements for tomorrow's best jobs: Helping educators provide students with skills and tools they need (IDC White Paper). Retrieved from http://news.microsoft.com/download/presskits/education/docs/idc/101513

Anderson, G., \& Arsenault, N. (2005). Fundamentals of Educational Research (2nd ed.). Routledge: Taylor \& Francis Group. https://doi.org/10.4324/9780203978221

Balarin, M., \& Benavides, M. (2010). Curriculum reform and the displacement of knowledge in Peruvian rural secondary schools: Exploring the unintended local consequences of global education policies. Bath: Routledge, Compare, 40(3), 311-325. https://doi.org/10.1080/03057920903374440

Barton, P. E. (2006). High school reform and work: facing labour market realities. Princeton: Educational Testing Service.

Bloom, B. S. (Ed.) (1956). Taxonomy of educational objectives: The classification of educational goals, Handbook 1: Cognitive Domain. New York: McKay.

Carnevale, A, P., \& Hanson, A. (2015). Learn and earn: Connecting education to careers in the $21^{\text {st }}$ century. Retrieved from https://hdl.handle.net/10919/90764

Chandler, C. (1985). Curriculum and syllabus design. ELT Journal, 39, 101-104. https://doi.org/10.1093/elt/39.2.101

Chu, S. K. W, Reynolds, R. B., Tavares, N. I, Notari, M., \& Lee, C. W. Y. (2017). $21^{\text {st }}$ century skills development through inquiry-based learning: From theory to practice. Singapore: Springer Science Business Media. https://doi.org/10.1007/978-981-10-2481-8

Cohen, L., Manion, L., \& Morrison, K. (2011). Research methods in education (7th ed.). New York: Routledge.

Cornbleth, C. (1988). Curriculum in and out of context. Journal of curriculum and supervision, 3(2), 85-96. 
Cornbleth, C. (1990). Curriculum in context. New York: Falmer.

Danso, S. A. (2018). Moral education and the curriculum: The Ghanaian experience. International Journal of Scientific Research and Management, 6(1), 34-42. https://doi.org/10.18535/ijsrm/v6i1.el05

Darke, P., Shanks, G., \& Broadbent, M. (1998). Successful completing case study research: Combining rigour, relevance and pragmatism. Information Systems Journal, $8, \quad 273-289$. https://doi.org/10.1046/j.1365-2575.1998.00040.x

Dzobo. (1987). Speech delivered at the National Workshop on Educational Reform. Accra, Ghana.

Eash, M. J. (1991). Syllabus. In A. Lewy (Ed.), The international encyclopedia of curriculum. Oxford: Pergamon Press.

Ekwueme, L., Ofoha, O., Uchegbu, C. N., Anyikwa, B., \& Nkemdirim, M. (2009). A critical appraisal of the mode of implementation of Nigerian secondary school curriculum: towards socio-economic empowerment of youth. Research financed by Education Research Network for West and Central Africa (ERNWAC).

Ghana Education Service (2010). Teaching syllabi for senior high schools. Accra: Publishers.

Ghana Education Service (2014). Register of programmes and courses for public and private senior high schools, technical and vocational institutes. Accra: Publishers.

Harrow, A. J. (1972). A taxonomy of the psychomotor domain: A guide for developing behavioural objectives. New York: McKay.

Jansen, D. J. (1988). Curriculum change and contextual realities: an analysis of recent trends in Black South African education. International Review of Education, 34(3), 378-387. https://doi.org/10.1007/BF00598223

Krathwohl, D. R., Bloom, B. S., \& Masia, B. B. (1964). Taxonomy of educational objectives: The classification of educational goals. Handbook 2: Affective Domain. New York: McKay.

Macdonald, M. A., \& Rogan, J. M. (1985). The in-service teacher education component of an innovation: A case study in an African setting. Journal of Curriculum Studies, 17(1), 63-85. https://doi.org/10.1080/0022027850170106

Marie-Lou, H. C., Roos, W., Christiane, T., \& Jorgen, C. (2011). Instruments and guidelines for qualitative fieldwork. EUMAGINE Project Paper 6B.

Merriam, S. B. (2001). Qualitative research and case study applications in education. San Fransico. Josses-Ross Publisher.

Millar, C. (1984). Curriculum improvement or social innovation? A case study in teacher education at a Black South African University. Journal of Curriculum Studies, 16(3), 297-310. https://doi.org/10.1080/0022027840160307

Ministry of Education. (2002). Report of the Education Review Committee. Accra: Publishers.

Otunga, R. H., \& Nyandusi, C. (2013). The context of curriculum development in Kenya. Eldoret: Moi University Press.

Partnership for $21^{\text {st }}$ Century Skills. (2009). Curriculum and instruction: A $21^{\text {st }}$ century skills implementation guide. Retrieved Dec. 2015 from http://www.21stcenturyskills.org

Patton, M. O. (1980). Qualitative evaluation methods. Beverly Hills, CA: Sage.

Reeves, T. C. (2006). How do you know they are learning?: the importance of alignment in higher education. Int. J. Learning Technology, 2(4), 294-309. https://doi.org/10.1504/IJLT.2006.011336

Robson, C., \& McCartan, K. (2016). Real world research (4th ed.). West Sussex: John Wiley \& Sons.

Rosenbaum, J. (2005). Educational Opportunity in American Society: A Research Agenda for Studying Transitions. Learning Point Associates, a paper given at the Institute of Education Science Conference on Research for Improving High Schools.

Seidman, I. (2013). Interviewing as qualitative research: A guide for researchers in education and the social sciences (3rd ed.). New York: Teachers College Press.

Yin, R. K. (2002). Case study research: Design and methods (3rd ed.). Sage Publications, Thousand Oaks. 